\title{
PENGARUH KONFIGURASI POLITIK TERHADAP PRODUK HUKUM PADA MASA PEMERINTAHAN SOEHARTO DI INDONESIA
}

\author{
Ryan Muthiara Wasti ${ }^{1}$
}

\begin{abstract}
Abstrct
Soeharto government becomes an interesting theme for nearly every research because of the uniqueness of the rule known as the authoritarian nature. However, the uniqueness is only studied until the result of the authoritarian who has raised the swelter of almost all the people and eventually led to the cessation of Soeharto as the head of the State Indonesia. Yet seen from the eyes of the law, the political transition in the future not only of political influence, but also legally so as to distinguish between authoritarian rule and democratic governance. This study will address these problems are divided into two: the first part will look at the political configuration that occurred in Indonesia during the transition from Sukarno government towards the Soeharto government, and the second part will analyze the form of a legal product that is formed from the political configuration that was built after the The transition compared to the legal product before and after the transition period. With two issues are expected to show how a head of state will govern affect measures taken shape, which certainly will be poured in the form of legislation. Tentative conclusions is that there is significant influence between the political configuration with legal products produced by the legislature during the reign of the.
\end{abstract}

Keywords: configuration political, legislative, legal products responsive

\begin{abstract}
Abstrak
Pemerintahan Soeharto menjadi sebuah tema menarik bagi hampir setiap penelitian karena keunikan dari pemerintahannya yang dikenal dengan sifat otoriter. Namun, keunikan tersebut hanya diteliti hingga akibat dari otoriternya yang telah menimbulkan kegerahan dari hampir seluruh rakyat dan akhirnya berujung pada berhentinya Soeharto sebagai kepala Negara Indonesia. Padahal dilihat dari kacamata hukum, transisi politik pada masa tersebut tidak hanya berpengaruh secara politik, tetapi juga secara hukum sehingga dapat dibedakan antara pemerintahan yang otoriter dan pemerintahan yang demokratis. Penelitian ini akan membahas permasalahan tersebut yang dibagi atas dua yaitu bagian pertama yang akan melihat konfigurasi politik yang terjadi di Indonesia pada masa transisi dari pemerintahan Soekarno menuju pemerintahan Soeharto, serta bagian kedua
\end{abstract}

\footnotetext{
${ }^{1}$ Peneliti Pusat Studi Hukum Tata Negara Fakultas Hukum Universitas Indonesia. Alamat kontak; ryan.muthiara@gmail.com.
} 
yang akan menganalisis bentuk produk hukum yang dibentuk dari konfigurasi politik yang dibangun setelah masa transisi tersebut dibandingkan dengan produk hukum sebelum dan sesudah masa transisi. Dengan dua permasalahan tersebut diharapkan dapat memperlihatkan bagaimana seorang kepala negara memerintah akan mempengaruhi bentuk kebijakan yang diambil yang pastinya akan dituangkan dalam bentuk legislasi. Kesimpulan sementara adalah ada pengaruh yang signifikan antara konfigurasi politik dengan produk hukum yang dihasilkan oleh lembaga legislatif pada masa pemerintahan tersebut.

Kata kunci: konfigurasi politik, legislatif, produk hukum responsif

\section{Pendahuluan}

Undang-Undang Dasar 1945 merupakan konstitusi yang tidak hanya sekadar konstitusi formal yang hanya mengatur hubungan kekuasaan dalam negara, artinya negara bukan dilihat sebagai house of power tetapi menjangkau semua hubungan kekuasaan negara secara vertikal maupun horizontal serta mengatur hingga hak asasi manusia. ${ }^{2}$ Artinya, konstitusi menjadi arahan dalam pembangunan hukum nasional bukan legal order semata. Konstitusi diejawantahkan dalam peraturan perundang-undangan yang dijadikan peraturan dalam kehidupan sehari-hari.

Dalam penerapannya di Indonesia, konstitusi ini dilaksanakan oleh organ-organ negara itu sendiri. Peraturan perundang-undangan yang ada di Indonesia sebagai negara demokrasi membutuhkan peran semua warga negaranya baik laki-laki maupun perempuan di parlemen. ${ }^{3}$ Dengan jumlah penduduk yang seimbang antara laki-laki dan perempuan, ${ }^{4}$ maka tidak hanya laki-laki yang mempunyai peran di parlemen tetapi juga perempuan.

Di parlemen, perempuan berperan dalam pembahasan isu-isu pembangunan seperti pendidikan, lingkungan, layanan sosial serta memastikan dihasilkannya produk hukum yang melindungi kepentingan perempuan. ${ }^{5}$ Hal

2 Komisi Hukum Nasional, "Akar-Akar Mafia Peradilan di Indonesia; Masalah Akuntabilitas Penegak Hukum”, (Jakarta: Komisi Hukum Nasional, 2009), hal. 17.

${ }^{3}$ Dina Martiany, "Siginifikansi Representasi Perempuan di Parlemen”, (Jakarta: P3DI Sekretariat Jenderal DPR Republik Indonesia, 2011), hlm. 17. Menurut Subono, "Tidak ada demokrasi sejati dan tidak ada partisipasi masyarakat sesungguhnya dalam pemerintahan dan pembangunan tanpa adanya partisipasi laki-laki dan perempuan”. Ibid.

${ }^{4}$ Berdasarkan data dari Biro Pusat Statistik (BPS) tahun 2010, terdapat 118.010.413 atau sekitar 49,65\% jumlah perempuan dari total penduduk Indonesia, tetapi hanya $8 \%$ hingga $10 \%$ saja yang terpilih dalam setiap pemilu. Sementara itu, DPRD hanya diwakili oleh 44 orang atau 9,1\% perempuan. Data ini didukung fakta bahwa 30 provinsi di Indonesia, tidak satupun terdapat perempuan yang memimpin, sedangkan dari 336 kabupaten hanya 6 daerah yang dipimpin oleh perempuan. Badan Pusat Statistik, Hasil Sensus Penduduk 2010, diunduh dari <http://dds.bps.go.id/ eng/aboutus.php?sp=0>, pada 18 Juni 2012 pukul 15.56 WIB. 
ini didukung oleh demokrasi yang menuntut perwakilan bagi semua kelompok masyarakat agar aspirasinya tersalurkan melalui perwakilan. ${ }^{6}$

Berdasarkan data dari Biro Pusat Statistik (BPS) tahun 2010, terdapat 118.010.413 atau sekitar 49,65\% jumlah perempuan dari total penduduk Indonesia, ${ }^{7}$ tetapi hanya $8 \%$ hingga $10 \%$ saja yang terpilih dalam setiap pemilu. Sementara itu, DPRD hanya diwakili oleh 44 orang atau 9,1\% perempuan. Data ini didukung fakta bahwa 30 provinsi di Indonesia, tidak satupun terdapat perempuan yang memimpin, sedangkan dari 336 kabupaten hanya 6 daerah yang dipimpin oleh perempuan. ${ }^{8}$

Keberadaan perwakilan perempuan maupun laki-laki dalam pemerintahan berhubungan dengan bagaimana bentuk kebijakan serta pengambilan keputusan terhadap permasalahan yang terjadi. Pengambilan keputusan ini mencakup semua bidang kehidupan, mulai dari pendidikan, kesehatan, perekonomian hingga politik itu sendiri. Peran wakil dari rakyat adalah untuk menyalurkan aspirasi yang ada di masyarakat secara umum yang merupakan bagian dari tanggung jawab negara. Dengan jumlah penduduk yang hampir seimbang antara laki-laki dan perempuan, maka dapat dipastikan bahwa tidak hanya laki-laki yang mempunyai peran di lembaga perwakilan rakyat tetapi juga perempuan harus turut serta berada di lembaga perwakilan rakyat. Hal ini dikarenakan perempuan mempunyai kemampuan juga ketika diberi kesempatan untuk berpartisipasi dan mengambil keputusan, hanya tinggal bagaimana perempuan mendapatkan akses untuk diberi kesempatan itu. ${ }^{9}$

Salah satu upaya dalam rangka membangun hukum yang responsif terhadap segala permasalahan yang terus silih berganti dalam kehidupan bermasyarakat, berbangsa dan bernegara, yang juga dibarengi dengan pesatnya perkembangan informasi dan teknologi, telah ikut mempengaruhi tatanan

${ }^{5}$ IIca Luciak, "Pengawasan Parlementer atas Sektor Keamanan dan Gender", lampiran, (Jenewa: Geneva Center for The Democratic Control of Armed Forces (DCAF), 2008), hal. 6.

${ }^{6}$ Ramlan Subakti, dkk, "Meningkatkan Keterwakilan Perempuan", (Jakarta: Kemitraan Bagi Pembaruan Tata Pemerintahan, 2011), hal. 3. Menurut Robert A Dahl, ada delapan jaminan konstitusional yang menjadi syarat perlu untuk demokrasi, yaitu: pertama, kebebasan untuk membentuk dan mengikuti organisasi, kedua, adanya kebebasan berekspresi, ketiga, adanya hak memberi suara, keempat adanya eligibilitas untuk menduduki jabatan publik, kelima, adanya hak para pemimpin politik untuk berkompetisi secara sehat merebut dukungan dan suara, keenam, adanya tersedia sumber-sumber infromasi alternatif, ketujuh, adanya pemilu yang bebas dan adil, kedelapan, adanya institusi-institusi untuk menjadikan kebijakan pemerintah tergantung pada suara-suara (pemilih, rakyat) dan ekspresi pilihan (politik) lainnya. Robert A Dahl sebagaimana dikutip oleh Richard W. Krouse, Polyarchy \& Participation: The Changing Democratic Theory of Robert Dahl dalam “Polity”, Vol. 14, No. 3, (Spring, 1982), hal. 441-463.

7 Badan Pusat Statistik, Hasil Sensus Penduduk 2010, diunduh dari <http://dds.bps.go.id/ eng/aboutus.php?sp=0>, pada 18 Juni 2012 pukul 15.56 WIB.

${ }^{8}$ Budi Shanti, Kuota Perempuan Parlemen: Jalan Menuju Kesetaraan Politik, dalam “Jurnal Perempuan”, No. 19, (Jakarta: Yayasan Jurnal Perempuan, 2001), hal. 21-22.

${ }^{9}$ Kata Sambutan Menteri Negara Pemberdayaan Perempuan dalam Endang Moerdopo, Perempuan Keumala, (Jakarta: Grasindo, 2008), hal. xi. 
kehidupan yang berdampak pada terjadinya perubahan secara progresif dalam kehidupan berkeluarga, bermasyarakat, berbangsa dan bernegara adalah perlu ada suatu tatanan kehidupan yang didasarkan pada ketentuan Peraturan Perundang-undangan yang sensitif sekaligus responsif terhadap berbagai hal perubahan yang terjadi dalam masyarakat. ${ }^{10}$ Hal ini dilihat dari peraturan perundang-undangan sebagai sebuah norma yang mengatur masyarakat. Maka, keberadaannya diharapkan mampu menampung berbagai macam kebutuhan dan kepentingan yang ada di dalam masyarakat itu sendiri meskipun hal ini menjadi sebuah dilema baru bagi pembentuk peraturan perundang-undangan itu sendiri.

Dilihat dari beberapa pemerintahan, mulai dari Soekarno, Soeharto, hingga Soesilo Bambang Yudhoyono, terdapat korelasi antara bentuk kekuasaan yang digunakan oleh kepala negarannya dengan produk hukum yang dihasilkan. Era pemerintahan Soeharto misalkan dikenal sebagai era transisi sejak dideklarasikannya kemerdekaan Indonesia pada 17 Agustus 1945. Soeharto mendapat amanat sebagai presiden sebagai bentuk kecaman terhadap pemerintahan Soekarno yang lebih memperlihatkan kediktatorannya sebagai presiden dibandingkan sebagai seorang pemimpin bangsa. Soekarno mengeluarkan sejumlah kebijakan yang dianggap terlalu subjektif, misalkan dikeluarkannya Tap MPR No tentang pembubaran dewan perwakilan rakyat dan konstituante. Soekarno bahkan membuat Tap MPR yang berisi penegasan kepemimpinannya yang tanpa batas masa jabatan alias seumur hidup. Istana menjadi menguat, partai-partai lain selain PKI menjadi lemah dan bahkan kekuatan militer pun menguat. Selain itu, kegoncangan lainnya melanda pemerintahan Soekarno pada saat ada aksi mahasiwa yang menunutut dibubarkannya PKI karena merusak tatanan demokrasi di Indonesia. ${ }^{11} \mathrm{Hal}$ ini disebabkan karena kenyataannya PKI yang menjadi andalan dari Soekarno untuk menjadi mitra kerja ternyata membelot dan justru melakukan pemberontakan.

Setelah melalui proses perdebatan dan berbagai pro dan kontra dari kebijakannya, Soekarno pun lengser dalam ketetapan Sidang Istimewa MPRS pada tanggal 7 Maret 1967 dan menandai berakhirnya kekuasaan orde lama dan digantikan oleh Soeharto. ${ }^{12}$

Dalam masa transisi dari Soekarno ke Soeharto, terdapat proses yang cukup singkat dimana Soeharto bisa dengan cepat melalui proses transisi tersebut. Pada masa Soeharto, dukungan militer menjadi sebuah unsur yang tidak bisa dilepaskan. Hal ini juga dipengaruhi oleh adanya prinsip yang dipegang di awal pemerintahan Soeharto yaitu melaksanakan UUD 1945

\footnotetext{
${ }^{10}$ Parameter Kesetaraan Gender dalam Pembentukan Peraturan Perundang-Undangan (Jakarta: Kementerian Pemberdayaan Perempuan dan Anak, 2012), hlm. 1.

${ }^{11}$ Ramly Hutabarat, "Politik Hukum Pemerintahan Soeharto tentang Demokrasi Politik di Indonesia”, (Jakarta: Pusat Studi Hukum Tata Negara FHUI: 2005), hal. 22.

${ }^{12}$ Ibid., hal. 23.
} 
secara murni dan konsekwen yang tercermin dari beberap kebijakannya. Namun, pada kenyataannya, semua kebijakan demokrasi ekonomi dan politik tidak sesuai dengan UUD 1945. Politik hukum lama kelamaan menjadi politik kekuasaan yang diperankan Soeharto sebagai sebuah alat untuk mempertahankan jabatan yang sudah ada ditangan.

Ada banyak kebijakan yang ternyata menjadikan negara Indonesia ini dari sistem demokrasi menuju otoriter terjadi, padahal yang diharapkan dari penggantian Soekarno ke Soeharto adalah terwujudnya Indonesia yang demokratis. Oleh karena itu, penting untuk melihat sejauh mana kediktatoran Soeharto dalam melaksanakan politik hukum nya di Indonesia dengan melihat pengaruh dari konfigurasi politik yang dianut pada masa pemerintahannya dengan produk hukum responsif yang dihasilkan oleh lembaga perwakilan rakyat di Indonesia atau produk hukum yang dikeluarkan oleh kepala negara sebelum dan masa pemerintahan Soeharto. Adapun yang menjadi pokok permasalahan dalam penelitian ini adalah: 1. Bagaimana konfigurasi politik yang terjadi di Indonesia pada masa transisi dari pemerintahan Soekarno menuju pemerintahan Soeharto? 2. Bagaimana bentuk produk hukum yang dibentuk dari konfigurasi politik yang dibangun setelah masa transisi tersebut dibandingkan dengan produk hukum sebelum masa transisi?

Penulis menggunakan dua teori dalam pembahasan yaitu:

\section{Pembentukan Peraturan Perundang-Undangan}

Hans Kelsen dalam bukunya General Theory of Law menyebutkan bahwa $^{13}$ ada dua sistem norma, yaitu sistem norma yang statik (nomostatic) dan sistem norma yang dinamis (nomodynamic). Sistem norma yang statik (nomostatics) adalah sistem yang melihat pada isi norma. Menurut norma statik, suatu norma umum dapat ditarik menjadi norma-norma khusus, atau norma khusus tersebut dapat ditarik dari suatu norma umum. Penarikan norma khusus dari norma umum tersebut diartikan bahwa norma umum tersebut dirinci menjadi norma yang khusus dari segi isinya. Sementara sistem norma dinamik (nomodynamics) adalah sistem norma yang melihat pada berlakunya suatu norma atau dari cara pembentukannya atau penghapusannya.

Law is anything that has come about in the way constitution prescribes for the creation of law... According to this concept, law is something created by a certain process, and everything created in this way is law. ${ }^{14}$

Peraturan perundang-undangan merupakan implementasi dari norma hukum yang ada di dalam masyarakat. Norma adalah suatu ukuran yang

\footnotetext{
${ }^{13}$ Hans Kelsen, "General Theory of Law and State", (London: Oxford University Press, 1949), hal. 122.

${ }^{14}$ Ibid., hal. 123.
} 
harus dipatuhi oleh seseorang dalam hubungannya dengan sesamanya ataupun dengan lingkungannya. ${ }^{15}$ Norma hukum dapat dibentuk secara tertulis maupun tidak tertulis oleh lembaga-lembaga yang berwenang membentuknya, sedangkan norma-norma moral, adat, agama dan lainnya terjadi secara tidak tertulis tetapi tumbuh dan berkembang dari kebiasaan-kebiasaan yang ada dalam masyarakat. Norma hukum yang tertulis inilah yang disebut dengan peraturan perundang-undangan.

Sedangkan mengenai pembentukan peraturan perundang-undangan, Hans Kelsen mempunyai pandangan bahwa: ${ }^{16}$

An important stage in the law creating process is the procedure by which general norms are created, that is procedure legislation. ...... As a matter of fact, many a law - in this formal sense of the term- contains not only legal norms, but also certain elements which are no specific legal, ie normative, character, such as, purely theoritical views concerning certain matters, the motives of legislator, political ideologies contained in references such as "justice" or the will of God, etc.

Mengenai apa yang dimaksud dengan peraturan perundang-undangan menurut Hans Kelsen adalah:

This doesn't mean, however, that everything which has been created according to this procedure is law in the sense of a legal norm. It is a legal norm only if it purpots to regulate human behaviour, and if it regulates human behavior by providing an act of coercion as sanction.

Soejono Soekanto menyebutkan kekuatan berlakunya peraturan perundang-undangan dapat dilihat secara sosiologis yang intinya adalah efektivitas kaedah hukum di dalam kehidupan bersama. ${ }^{17}$ Mengenai hal ini dikenal dua teori:

1) Teori Kekuasaan ("Machttheorie"; "The Power Theory") yang pada pokoknya menyatakan bahwa kaedah hukum mempunyai kelakuan sosiologis, apabila dipaksakan berlakunya oleh penguasa, diterima ataupun tidak oleh warga-warga masyarakat; ${ }^{18}$

2) Teori Pengakuan ("Anerkennungstheorie", "The Recognition Theory" ) yang berpokok pangkal pada pendapat, bahwa kelakuan hal. 18 .

15 Maria Farida Indrati, "Ilmu Perundang-Undangan”, (Yogyakarta: Kanisius, 2011),

${ }^{16}$ Hans Kelsen, Op. Cit.

17 Soerjono Soekanto \& Purnadi Purbacaraka, "Perihal Kaedah Hukum", (Bandung: Citra Aditya Bakti, 1993), hal. 88-92.

${ }^{18}$ Ibid., 
kaedah hukum didasarkan pada penerimaan atau pengakuan oleh mereka kepada siapa kaedah hukum tadi tertuju. ${ }^{19}$

A Hamid S. Attamimi menegaskan keberlakuan suatu peraturan perundang-undangan dengan adanya asas pembentukan peraturan perundang-undangan yang baik yang secara formal salah satunya adalah asas dapatnya dilaksanakan. ${ }^{20}$ Artinya sebuah peraturan perundangundangan haruslah dibuat sedemikian rupa agar dapat dilaksanakan, maka tentunya peraturan yang dibuat tersebut adalah peraturan yang memang dibutuhkan atau sesuai dengan kepentingan masyarakat.

\section{Teori Perwakilan Rakyat}

Perwakilan politik yang diejawantahkan dengan parlemen dapat dipahami sebagai kehadiran anggota-anggota kelompok ke dalam lembaga-lembaga politik. ${ }^{21}$ Kehadiran ini diartikan tidak hanya sekadar memenuhi kehadiran, namun hadir dengan segala ide, pemikiran dari kelompok yang diwakilinya. ${ }^{22}$ Pada tingkat yang sederhana, para wakil bertindak demi kelompok yang mereka wakili. ${ }^{23}$ Namun, dalam demokrasi representatif sebagian besar dari mereka yang dipilih untuk badan pembuat undang-undang bertindak bagi banyak kelompok yang berbeda, dan sebagian besar juga berusaha untuk mengatasi kepentingankepentingan kelompok yang sempit dan terutama bertindak bagi bangsa atau komunitas yang dilayani itu. ${ }^{24}$ Dengan prinsip perwakilan sebagai pihak yang merepresentasikan kepentingan orang lain, maka timbul sebuah pertanggungjawaban yang berhubungan dengan tindakan yang

${ }^{19}$ Ibid.

${ }^{20}$ Maria Farida Indrati, Op. Cit., hal. 256.

Asas pembentukan peraturan perundang-undangan yang baik menurut A Hamid $\mathrm{S}$ Attamimi,yaitu:

1. Asas tujuan yang jelas;

2. Asas perlunya pengaturan;

3. Asas organ/lembaga yang tepat;

4. Asas materi muatan yang tepat;

5. Asas dapat dilaksanakan;

6. Asas dapatnya dikenali.

21 Stanford Encylopedia of Philosophhy, Political Representation, diunduh dari <http://plato .stanford.edu/entries /political-representation/>, pada 10 Oktober 2012 pukul 14.29 WIB.

${ }^{22}$ Ibid.

${ }^{23}$ J.H.A. Logeman, "Theory of a Positive Constitutional Law, (Over De Theorie Van Een Stelling Staatsrecht)”, terj, (Perancis: Universitaire Pers Leiden, 1948), hal. 135.

${ }^{24}$ Ibid. 
diambil sebagai bentuk penyaluran aspirasi dan bersifat formal di lingkungan jabatannya. ${ }^{25}$ yaitu: ${ }^{26}$

Perwakilan politik secara umum terdiri atas beberapa komponen

1) pihak yang mewakili (wakil, organisasi, gerakan, lembaga negara, dan lain-lain);

2) pihak yang diwakili (konstituen, klien, dan lain-lain);

3) sesuatu yang sedang diwakili (pendapat, perspektif, kepentingan, wacana, dan lain-lain);

4) pengaturan di mana aktivitas representasi berlangsung (konteks politik).

Sehubungan dengan komponen tersebut, Hanna Pitkin mengemukakan di dalam bukunya the concept of representation bahwa salah satu teori representasi adalah descriptive representative, yaitu gagasan bahwa wakil terpilih dalam demokrasi harus mewakili tidak hanya diekspresikan dari konstituen mereka (atau bangsa secara keseluruhan), tetapi juga orang-orang dari karakteristik deskriptif mereka yang secara politik relevan, seperti wilayah geografis kelahiran, etnisitas pekerjaan, atau gender. ${ }^{27}$ Menurut ide ini, badan terpilih harus menyerupai sampel yang representatif dari para pemilih mereka sehingga mewakili karakteristik luar konstituen, misalnya perbandingan perempuan $50 \%$ dan $20 \%$ kulit hitam, maka legislator yang mewakilinya juga harus $50 \%$ perempuan dan $20 \%$ kulit hitam. $^{28}$

Teori deskriptif representatif ini diperkuat dengan pendapat Williams yang menjelaskan bagaimana perwakilan perlu memediasi hubungan

${ }^{25}$ Ibid.

${ }^{26}$ Stanford Encyclopedia of Philosophhy, Loc. Cit.

${ }^{27}$ Hanna Fenichel Pitkin, "The Concept of Representation”, (London: University of California Press, 1967), hal. 38. Teori tentang representasi lainnya yang juga dikemukakan oleh Hanna adalah sebagai berikut:

1. formalistic representation yaitu perwakilan berdasarkan formalitas kedudukan seseorang. Teori ini mengacu pada dua dimensi yaitu otoritas (pemindahtanganan wewenang dari yang diwakili kepada perwakilan) dan akuntabilitas (tanggungjawab atau respon dari perwakilan terhadap yang diwakili).

2. symbolic representation, yaitu perwakilan yang hanya secara simbol saja, kewenangan dan tanggungjawab tetap berada di tangan yang diwakili.

3. substantive representation yaitu secara pemaknaan, seorang perwakilan memaknai suatu kepentingan yang diwakilinya itu adalah kepentingan dia juga sehingga secara subtanti ia dapat mewakili yang diwakilinya walaupun secara fisik tidak mewakili yang diwakilinya tersebut. Perwakilan diharapkan dapat memenuhi kebutuhan secara psikologis dari pihak yang diwakili.

Ibid., hal. 38-92.

$$
{ }^{28} \text { Ibid. }
$$


perwakilan-konstituen dalam rangka membangun kepercayaan. $^{29}$ Kepercayaan adalah landasan untuk akuntabilitas demokratik. ${ }^{30}$ Williams menunjukkan pola pengkhianatan oleh warga kulit putih yang tidak mempercayai wakil selain dari kulit putih juga atau institusi mereka sendiri, maka hubungan ketidakpercayaan tersebut bisa setidaknya sebagian diperbaiki jika kelompok yang kurang beruntung diwakili oleh anggota sendiri. ${ }^{31}$

John Stuart Mill menyatakan bahwa sistem proportional representation adalah sebuah sistem yang paling baik karena sistem ini mampu menciptakan parlemen yang menggambarkan kharakteristik masyarakat karena ada peluang bagi partai kecil atau minoritas untuk memiliki wakil di parlemen sepanjang partai tersebut memenuhi kuota suara untuk memenangkan satu kursi. ${ }^{32}$

Menurut Jimly Asshiddiqie, keseimbangan antara kedua kepentingan rakyat dengan kepentingan nasional akan dapat dijamin apabila kedekatan antara rakyat dengan wakilnya dapat dikaitkan dengan fungsi keterwakilan secara fisik dan keterwakilan secara substantif tersebut. ${ }^{33}$ Kedekatan wakil rakyat secara fisik dengan rakyat dapat meningkatkan kinerja dari para wakil serta dapat memberikan pelayanan yang sesuai dengan kebutuhan rakyat. ${ }^{34}$

\section{Teori Hukum Responsif}

Philippe Nonet dan Philip Selznick dalam bukunya Law and Society in Transition: Toward Responsive Law menyebutkan ada tiga bentuk hukum yang dipengaruhi oleh politik hukum suatu negara yaitu: ${ }^{35}$

1. Represive Law: governing power is represive when it gives short shrift to the interests of the governed, that is, Loc Cit.

${ }^{29}$ Melissa Williams, sebagaimana dikutip dari Stanford Encyclopedia of Philosophhy,

${ }^{30}$ Ibid.

${ }^{31}$ Ibid.

32 Afan Gafar, Konsekuensi Perubahan Sistem Pemilu, dalam Abdul Bari Bazed, “Sistem-Sistem Pemilihan Umum: Suatu Himpunan Pemikiran", Ed. 1, Cet. 1, (Jakarta: Badan Penerbit Fakultas Hukum Universitas Indonesia, 2000), hal. 72.

${ }^{33}$ Jimly Asshidiqie, Op. Cit., hal. 26-27.

${ }^{34}$ Ibid.

${ }^{35}$ Philip Nonet and Philip Selznick, "Law and Society in Transition: Toward Responsive Law”, dalam Satya Arinanto, “Bahan Ajar Politik Hukum 2”, (Jakarta: Program Pascasarjana Fakultas Hukum Universitas Indonesia, 2004), hal. 73-156. 
dispossed to disregard those interest or deny their legitimacy. The characteristic of represive law is: ${ }^{36}$

a. Legal institutions are directly accessible to political power; law is identified with the state and subordinated to raison d'etat

b. The conversation of authority is an overriding preoccupation of legal officialdom. In the official perspective that ensues, the benefit of the doubt goes to the system, adn administrative conveninence weighs heavily.

c. Specialized agencies of control, such as the police, become independent centers of power, they are isolated from moderating social contexts and capable of resisting political authority

d. A regime of dual law institutionalizes class justice by consolidating and legitimating patterns of social subordination

e. The criminal code mirrors the dominant mores, legal moralism prevails

2. Autonomous Law; the chief characteristic of this system is the formation of specialized, relatively autonomous legal intitutions that claim a qualified supremacy within defined spheres of competence. Another attributes of autonomous law may be summarized as follows:

a. Law is separated from politics.

b. The legal order espouses tho model of rules

c. Procedure is the heart of law

d. Fidelity to law is understood as strict obedience to the rules of positive law.

3. Responsive Law: presumes that purpose can be made objective enough and authoritative to control adaptive rule making. Responsive law presupposes a society that has the political and make the neccesary commitments. ${ }^{37}$ Law. $^{38}$

Salah satu dari tiga jenis teori hukum tersebut yaitu Responsive

36 Ibid., hal. 77. Philip Nonet dan Philip Selznick mengatakan bahwa pada kenyataannya, secara ekonomi, hukum represif terjadi di negara-negara yang paling totaliterisme dalam masa modern ini.

${ }^{37}$ A third type of law strives to resolve that tension. We call it responsive, rather than open or adapative, to suggest a capacity for responsible, and hence discriminate and selective, adaptation. Ibid., hal. 121.

${ }^{38}$ Ibid., hal. 117. 
A third type of law stripes to resolve that tension, we call it responsive, rather than open or adaptive, to suggest capacity for responsible, and hence discriminate and selective, adaptation. A responsive institution retains a grasp on what is essential to its integrity while taking account of new forces in its envirounment.

Jenis ketiga yang disebutkan oleh Philippe Nonet dan Philip Selznick yaitu hukum responsif yaitu hukum yang memiliki sensitivitas terhadap permasalahan di lingkungannya namun bertanggungjawab. Itulah mengapa tidak disebut dengan hukum adaptif tetapi responsif, dimana pada kata adaptif hanya ada unsur empati dan penyesuaian dengan lingkungan saja tanpa rasa tanggungjawab.

\section{Konfigurasi Politik Di Indonesia Periode 1932-1998}

Era pemerintahan Soeharto dikenal sebagai era transisi sejak dideklarasikannya kemerdekaan Indonesia pada 17 Agustus 1945. Soeharto mendapat amanat sebagai presiden sebagai bentuk kecaman terhadap pemerintahan Soekarno yang lebih memperlihatkan kediktatorannya sebagai presiden dibandingkan sebagai seorang pemimpin bangsa. Soekarno mengeluarkan sejumlah kebijakan yang dianggap terlalu subjektif, misalkan dikeluarkannya Tap MPR No tentang pembubaran dewan perwakilan rakyat dan konstituante. Soekarno bahkan membuat Tap MPR yang berisi penegasan kepemimpinannya yang tanpa batas masa jabatan alias seumur hidup. Istana menjadi menguat, partai-partai lain selain PKI menjadi lemah dan bahkan kekuatan militer pun menguat. Selain itu, kegoncangan lainnya melanda pemerintahan Soekarno pada saat ada aksi mahasiwa yang menunutut dibubarkannya PKI karena merusak tatanan demokrasi di Indonesia. ${ }^{39} \mathrm{Hal}$ ini disebabkan karena kenyataannya PKI yang menjadi andalan dari Soekarno untuk menjadi mitra kerja ternyata membelot dan justru melakukan pemberontakan.

Setelah melalui proses perdebatan dan berbagai pro dan kontra dari kebijakannya, Soekarno pun lengser dalam ketetapan Sidang Istimewa MPRS pada tanggal 7 Maret 1967 dan menandai berakhirnya kekuasaan orde lama dan digantikan oleh Soeharto. ${ }^{40}$ Dalam masa transisi dari Soekarno ke Soeharto, terdapat proses yang cukup singkat dimana Soeharto bisa dengan cepat melalui proses transisi tersebut. Pada masa Soeharto, dukungan militer menjadi sebuah unsur yang tidak bisa dilepaskan. Hal ini juga dipengaruhi oleh adanya prinsip yang dipegang di awal pemerintahan Soeharto yaitu melaksanakan UUD 1945 secara murni dan konsekwen yang tercermin dari

\footnotetext{
${ }^{39}$ Ramly Hutabarat, "Politik Hukum Pemerintahan Soeharto tentang Demokrasi Politik di Indonesia", (Jakarta: Pusat Studi Hukum Tata Negara FHUI: 2005), hal. 22.

${ }^{40}$ Ibid., hal. 23.
} 
beberap kebijakannya. Namun, pada kenyataannya, semua kebijakan demokrasi ekonomi dan politik tidak sesuai dengan UUD 1945. Politik hukum lama kelamaan menjadi politik kekuasaan yang diperankan Soeharto sebagai sebuah alat untuk mempertahankan jabatan yang sudah ada ditangan.

Dalam hal demokrasi politik misalkan, Soeharto menerapkan adanya Penelitian Khusus (Litsus) bagi calon anggota legislatif yang berdasar pada Keppres Nomor 16 Tahun 1990 dengan tujuan baik untuk membersihkan dan menertibkan tubuh aparatur negara dari bahaya komunis dan kekuatan ekstrim lainnya. Namun, kenyataannya Litsus ini tidak lebih dari sekadar campur tangan kekuasaan untuk menentukan siapa calon-calon legislatif terpilih. ${ }^{41}$ Ada banyak kebijakan yang ternyata menjadikan negara Indonesia ini dari sistem demokrasi menuju otoriter terjadi, padahal yang diharapkan dari penggantian Soekarno ke Soeharto adalah terwujudnya Indonesia yang demokratis. Oleh karena itu, penting untuk melihat sejauh mana kediktatoran Soeharto dalam melaksanakan politik hukum nya di Indonesia.

Pasal 3 ayat (1) Undang-Undang Dasar Republik Indonesia menyebutkan bahwa kedaulatan ada di tangan rakyat dan didasarkan pada Undang-Undang Dasar. ${ }^{42}$ Hal ini mencerminkan bahwa kedaulatan berada di atas segala di atas segalanya. Kedaulatan rakyat yang disebut juga dengan supremasi rakyat merupakan salah satu unsur yang ditempatkan paling kuat dalam bentuk pemerintahan yang demokratis. ${ }^{43}$ Helena Catt menegaskan mengenai prinsip kedaulatan rakyat yaitu:"control to ideas of representatives democracy is the idea that people have power because they choose representatives are regularly accountable to the voters for the decisions that they make for collectivity". 4 Maka, rakyat memiliki kekuatan sebagai control dari demokrasi itu sendiri. Keberadaan rakyat menjadi sangat penting dan tonggak dari berdirinya sebuah Negara demokrasi. Rakyat menjadi subjek sekaligus objek dan berkuasa independensi dirinya sendiri. Timbulnya gagasan kedaulatan rakyat adalah sebagai reaksi dari adanya monopoli kekuasaan dan penyimpangan yang dilakukan terhadap rakyat. ${ }^{45}$

Meskipun demikian, Max Weber mendefenisikan negara sebagai sebuah komunitas manusia yang berhasil mengklaim monopoli penggunaan yang sah atas kekuataan fisik dalam sebuah teritori tertentu. ${ }^{46}$ Artinya, unsur paksaan

\footnotetext{
${ }^{41}$ Ibid., hal. 17-18.

${ }^{42}$ Republik Indonesia, Undang-Undang Dasar 1945 Perubahan Keempat, Pasal 3 ayat

${ }^{43}$ Ramly Hutabarat, "Politik Hukum Pemerintahan Soeharto tentang Demokrasi Politik di Indonesia", (Jakarta: Pusat Studi Hukum Tata Negara FHUI: 2005), hal. 1.

${ }^{44}$ Helena Catt, "Democracy in Practice”, (London and Newyork: Routledge, 1999),
} $(1)$. hal. 45 .

\footnotetext{
${ }^{45}$ Hendra Nurtjahyo, "Filsafat Demokrasi”, (Jakarta: Bumi Aksara, 2006), hal. 33.
} 
menjadi unsur utama dalam sebuah negara. Jika tidak ada unsur paksaan ini maka negara akan menjadi lemah. Hal ini bisa menjadi salah satu penyebab dari adanya transisi yang dilakukan oleh negara-negara di dunia dari diktator menjadi negara demokratis.

Demokratisnya juga tergantung pada karakteristik dari pemerintah yang berkuasa atau bisa juga dilihat dari kebebasan yang diberikan kepada partai politik. ${ }^{47}$ Ramly Hutabarat mengemukakan dalam disertasinya bahwa ada beberapa hal yang memepengaruhi demokratis atau tidaknya sebuah pemerintahan yaitu:

1. Iklim dari pemerintahan yang sedang berkuasa. Pemerintahan yang demokratis akan memberikan kesempatan pada tumbuhnya partai-partai politik.

2. Kemauan politik pemerintahan yang berkuasa. Demokrasi atau tidaknya pemerintahan sangat tergantung pada selera atau kehendak siapa yang berkuasa. Di Indonesia hal ini terlihat dari masa pemerintahan Hindia Belanda dimana partai-partai politik dibatasi aktivitasnya sementara di masa pemerintahan Soekarno partai politik justru tumbuh menjamur.

3. Perubahan arus bawah. Dorongan yang begitu kuat yang menuntut adanya perubahan otoritarisme menjadi rezim yang demokratis. Dalam hal ini rakyat berperan dalam mendesak terjadinya demokrasi itu sendiri.

Syarat dari demokrasi berupa pembentukan partai politik merupakan hal yang tidak dapat ditutup atau ditahan kecuali bagi partai politik yang diduga akan menghancurkan sifat demokratis Negara itu sendiri, misalkan dengan memunculkan gerakan separatism. ${ }^{48}$ Demokrasi ternyata terjadi tidak begitu saja, tetapi melaui sebuah proses melewati bentuk otoriter terlebih dahulu. Hal ini dikarenakan kekuasaan dalam suatu negara tidak dapat dipisahkan dari hukum. Dilihat dari perkembangannya, Negara-negara di dunia telah mengalami masa dimana otoriter mencoba berubah bentuk menjadi Negara demokratis. Gelombang transisi ini terjadi semenjak 1970-an. ${ }^{49}$ Negara-negara tersebut menjadikan demokrasi sebagai tujuan yang ideal dan mencoba dengan cara yang berbeda untuk menyelesaikan permasalahannya dengan masa lalu. Ada negara yang menjadikan pengalaman sebelumnya sebagai bahan pelajaran

${ }^{46}$ Fransi Fukuyama, "Memperkuat Negara: Tata Pemerintahan dan Tata Dunia Abad 21”, (Jakarta: Gramedia, 2004), hal. 8.

${ }^{47}$ Ramly Hutabarat, Op. Cit., hal. 2.

${ }^{48}$ Hal ini disampaikan oleh Prof Dr. Ismail Sunny dalam bukunya "Mencari Keadilan, Sebuah Otobiografi”, Ibid., hal. 17.

49 Satya Arinanto, "Hak Asasi Manusia dalam Transisi Politik di Indonesia", (Jakarta: Pusat Studi Hukum Tata Negara, 2008), hal. 97. Negara-negara yang mengalami transisi tersebut dimulai dari bagian Selatan Eropa (Yunani dan Spanyol), Amerika Latin (Argentina, Chile, Brazil, dan Uruguay), kemudian ke bagian timur Eropa (Polandia, Jerman Timur, dan Hongaria) dan Afrika Selatan serta negara-negara lainnya. 
untuk masa depan, ada juga negara yang melakukan pembersihan masa lalu dengan memperlihatkan tanggungjawab. Negara Chile memperlihatkan cara yang unik dimana Negara tersebut membuka kebenaran dari pelanggaranpelanggaran HAM dan dorongan terhadap suatu pengakuan publik akan kejahatan masa lalunya dan mendorong para korban untuk memberikan maaf atas kesalahan pelaku di masa sebelumnya. ${ }^{50}$ Hal ini setidaknya menggambarkan usaha dari Negara untuk membersihkan segala macam bentuk labeling yang diberikan terhadap pelaku-pelaku tersebut. Bahkan di Spanyol ada gerakan menuju "Negara bersih" yang bermakna sebuah pencarian untuk mengubur masa lalunya.

Indonesia sebagai Negara dengan kedaulatan rakyat juga mengalami masa transisi. ${ }^{51}$ Dari masa pemerintahan Hindia Belanda menuju pemerintahan Soeharto terdapat proses perubahan yang berbeda bentuk dan menjadi bahan dari evaluasi pemerintahan zaman sekarang untuk menjalankan demokrasi yang ideal. Soeharto menjadi pengganti Soekarno sebagai pemimpin yang otoriter. Kediktatorannya menimbulkan berbagai pro dan kontra. Kebijakan yang terjadi tidak memperlihatkan adanya demokrasi. Misalkan dalam hal pengangkatan MPR dan DPR. MPR dalam Pasal 1 ayat (3) Undang-Undang Dasar sebelum amandemen menyebutkan bahwa MPR terdiri dari: ${ }^{52}$

1. Utusan Daerah

2. Utusan Golongan Politik dan Golongan Karya

3. Utusan Golongan Karya Angkatan Bersenjata dan Golongan Karya bukan Angkatan Bersenjata yang ditetapkan berdasarkan pengangkatan.

Meskipun pengangkatan anggota MPR adalah sebanyak sepertiga dari total semua anggota MPR, tetapi masih bisa ditolerir karena dipandang ABRI sebagai golongan. Namun, yang paling jelas direkayasa adalah pengangkatan DPR yang seharusnya melalui pemilihan umum. Pasal 10 ayat (2) UndangUndang Nomor 16 Tahun 1969 mengatur bahwa: Pengisian keanggotaan DPR dilakukan dengan cara Pemilihan Umum dan pengangkatan. Jumlah anggota DPR adalah 460 orang. Partai-partai tidak dibiarkan tumbuh berkembang seperti yang terjadi di Negara- Negara demokrasi. Pembatasan ini terlihat dari hanya diperbolehkannya ada dua partai dengan satu golongan karya. Ketiga partai inilah yang hanya boleh ikut dalam pemilihan umum. Hal ini bertentangan dengan kebebasan berekspresi yang diatur dalam Pasal $28 \mathrm{D}$ 1945. Negara menjamin kebebasan berkespresi yang artinya pendirian partai politik pun sebagai implementasi dari ekspresi ini seharusnya juga tidak

${ }^{50}$ Ibid., hal. 112.

${ }^{51}$ Kedaulatan ini ada setelah pembentukan nation state pada proklamasi 17 Agustus 1945 sehingga Negara Republik Indonesia diakui sebagai subjek hukum internasional. Dari pembentukan inilah rakyat pun diakui sebagai kedaulatan tertinggi (democratic natie) Lihat Hendra Nurtjahjo, "Ilmu Negara: Pengembangan Teori Bernegara dan Suplemen", (Jakarta: PT Raja Grafindo Persada, 2005), hal. 31.

\footnotetext{
${ }^{52}$ Ramly Hutabarat, Op. Cit., hal. 63.
} 
dibatasi. Selain itu, pers juga tidak dibebaskan dalam menyampaikan pendapat sebagaimana yang diatur dalam Pasal 28 UUD 1945..$^{53}$

Pada akhirnya, pemerintahan Soeharto telah melahirkan beberapa permasalahan yang berhubungan dengan kekuasaan, yaitu: pertama, kekuasaan itu akan melahirkan ketidakadilan politik. Kedua, karena melakukan ketidakadilan politik maka akan menciptakan pula ketidakpuasan dan keresahan dalam masyarakat. Ketiga, ketidakpuasan dan keresahan yang berlangsung lama akan melahirkan gerakan antipati terhadap kekuasaan seperti protes, demonstrasi bahkan teror. Hal ini memperlihatkan gejala berjalannya demokrasi menuji otoriter, karena: ${ }^{54}$

1. Produk hukum dijadikan sebagai alat kekuasaan untuk mencapai tujuan kekuasaan. Salah satu tujuan kekuasaan adalah untuk mempertahankan usia kekuasaan. Dengan kekuasaan itu suatu pemerintahan melakukan apa saja yang dikehendakinya karena hukum telah dijadikan sebagai alat semata-mata.

2. Usia kekuasaan presiden yang terlalu lama akan membuka peluang untuk disalahgunakan, karena semakin lama seseorang berkuasa maka semakin cenderung disalahgunakan. Sekurang-kurangnya pihak-pihak yang berada di sekitar kekuasaan akan memanfaatkan kekuaasaan untuk kepentingan pribadi maupun golongan.

3. Terlalu dominannya peran militer dan dapat menimbulkan demokrasi tidak berjalan. ${ }^{55}$ Dominansi militer, walaupun ada kegunaannya tetapi melemahkan demokrasi sipil.

${ }^{53}$ Republik Indonesia, Perubahan Keempat Undang-Undang Dasar 1945, Pasal 28 D menyebutkan bahwa "Negara menjamin kebebasan tiap-tiap Negara untuk menyampaikan pendapat"

${ }^{54}$ Ramly Hutabarat, Op. Cit., hal. 57-58.

55 Turki misalkan, menghadapi rezim otoriter yang berkepanjangan setelah sebelumnya dipimpin oleh sipil yang membuat proses transisi di Turki menjadi unik karena militer tidak secara langsung mempimpin negara, tetapi mempengaruhi perpolitikan dari pendekatan dengan pemimpin. Lihat Syarif Taghian, "Erdogan; Muadzin Istanbul Penakluk Sekularisme Turki", (Jakarta: Al-Kautsar, 2012), hal. 21. Konstitusi Turki menunjukkan bahwa bentuk tatanan negara di Turki adalah Republik Demokratik Sekuler. Lihat Ibid., 59. Selain permasalahan politik, militer menjadi hal yang juga penting dalam transisi politik. Hal ini dikarenakan militer adalah bagian yang mendominasi pemerintahan otoriter sehingga transisi menuju demokratisasi akan berdampak pada dukungan dari militer terhadap supremasi sipil. Dukungan ini tentu harus diberikan oleh militer untuk mewujudkan negara demokrasi yang diimpikan dan butuh upaya yang signifikan. Militer pun akhirnya harus melakukan reformasi di tubuh lembaga ini sendiri seperti yang dilakukan di Indonesia dengan menerapkan lima langkah reformasi TNI, yaitu:

1. Pengurangan dalam perwakilan TNI-Polri di lembaga perwakilan rakyat;

2. Penghapusan kekaryaan (pengalihan sementara para perwira TNI-Polri ke posisi sipil);

3. Netralitas politik;

4. Pemisahan polisi dari TNI;

5. Orientasi pertahanan. 
Soeharto yang menjabat selama hampir 36 tahun menjadi bukti dari adanya pengaruh dari lamanya seseorang dalam jabatan tertentu membuat adanya kesewenang-wenanngan, hukum dijadikan alat politik untuk mempertahankan kekuasaaan. Politik dan hukum mempunyai hubungan, namun politik semestinya adalah peletakan signifikansi hukum dan etika atas fenomena kekuasaan. Politik tanpa hukum adalah kekuasaan yang liar, sebaliknya hukum tanpa politik hanyalah keinginan tanpa kuasa untuk bergerak. ${ }^{56}$ Hal ini terlihat dari konfigurasi kekuasaan yang diciptakan oleh Soeharto yang menunjukkan kekuasaan yang otoriter dan sentralistik. ${ }^{57}$

Arend Lijphart menyatakan bahwa beberapa hal yang merupakan karakteristik dari demokrasi yaitu diantaranya adanya pembagian kekuasaan baik secara formal maupun informal, sistem multipartai, veto yang kecil. ${ }^{58}$ Pada masa Soeharto ini tidak ada pembagian kekuasaan baik dari internal eksekutif itu sendiri atau dari legislatif dan yudikatif. Soeharto berperan sentral dan paling berkuasa selama masa pemerintahannya. Baik militer, golongan karya, ormas-ormas tidak lepas dari pengaruh Soeharto. Produk hukum yang dibuat jika dikehendaki oleh Soeharto akan menjadi undang-undang. Karakter jawa pedalaman yang halus dan tidak menyukai kritikan ternyata berpengaruh pada tipe kekuasaannya. ${ }^{59}$ Helena Catt menyatakan bahwa hal yang prinsip dari sebuah partisipasi demokrasi adalah ketika setiap orang feeling comfortable together, sharing knowledge, feeling equal respect and being able to criticise each other sehingga tidak ada ancaman untuk dapat bebas mengungkapkan pendapatnya. ${ }^{60}$ Selain itu, nilai-nilai demokrasi adalah nilai yang relevan dalam hal mengamankan hubungan antara masyarakat dengan pemerintah. ${ }^{61}$ Artinya

Lihat Satya Arinanto, "Hak Asasi Manusia dalam Transisi Politik di Indonesia", (Jakarta: Pusat Studi Hukum Tata Negara, 2008), hal. 100.

${ }^{56}$ Hendra Nurtjahjo, "Ilmu Negara: Pengembangan Teori Bernegara dan Suplemen", (Jakarta: PT Raja Grafindo Persada, 2005), hal. 8.

${ }^{57}$ Ramly Hutabarat, Op. Cit., hal. 59.

${ }^{58}$ Arend Lijphart, Op Cit. Ada beberapa karakteristik dari negara demokrasi yaitu:

1. Excecutive power-sharing: grand coalitions;

2. Separation of powers, formal and informal;

3. Balanced bicameralism and minority representation;

4. Multiparty system;

5. Multidimensional party system;

6. Proportional representation;

7. Teritorial and nonterritorial federalism and decentralization;

8. Written constitution and minority veto.

${ }^{59}$ Ramly Hutabarat, Op. Cit., hal. 59. Sebagai contoh ketika kelompok Petisi 50 menyampaikan kritiknya terhadap Soeharto berakibat pada kematian perdata dan hak-hak politik mereka ditiadakan. Lihat Ibid.

${ }^{60}$ Helena Catt., Op. Cit., hal. 52. 
jika tidak ada hubungan yang harmonis antara negara dengan pemerintah, maka negara tersebut tidak demokratis. Inilah yang juga melatar belakangi adanya Pasal 28 dan Pasal 28 E Undang-Undang Dasar 1945 menjamin adanya kebebasan untuk setiap orang berserikat, berkumpul dan mengemukakan pendapat selagi tidak menggangu hak orang lain. ${ }^{62}$

Pembentukan UU yang baik, harmonis dan mudah diterima oleh masyarakat merupakan salah satu kunci utama dalam penyelenggaraan pemerintahan suatu negara. Pasal 22A UUD NRI 1945 berbunyi: "ketentuan lebih lanjut tentang tata cara pembentukan undang-undang diatur dengan undang-undang,"menjadi dasar dari hukum yang berkaitan dengan teknik perundang-undangan terutama pada aspek teknis perancangannya (legal drafting). ${ }^{63}$ Maka, di dalam proses pembentukannya itu pun juga berdasar kepada konfigurasi politik yang sedang digunakan pada pemerintah.

Di dalam masa pemerintahan Orde Baru, banyak praktik yang dilakukan untuk mempertahankan kekuasaan yang cenderung otoriter. Beberapa praktik yang dilakukan oleh Orde Baru, antara lain. ${ }^{64}$

1. Orde Baru mampu mengkonsolidasikan dan membentuk kewenangan militer (ABRI) dengan kewenangan politik. Pada masa ini, doktrin dwifungsi ABRI sangat melekat, yakni fungsi ABRI sebagai penjaga pertahanan dan keamanan Indonesia, dan juga fungsi ABRI di ranah sosial politik.

2. Pemerintahan mengubah susunan pimpinan partai politik. Para pemimpin partai politik harus merupakan orang yang telah mendapatkan restu dari Presiden. Pada masa ini pula, Golkar dijadikan sebagai kendaraan politik bagi Orde Baru.

3. Pemerintah mendesain ideologi Pancasila sehingga menjadi pembenar bagi rezim oteritarian. Pancasila juga digunakan sebagai asas tunggal sebagai "simbol pemersatu". Pada masa ini, partai politik dan organisasi kemasyarakatan haruslah berasas Pancasila, dan tidak boleh yang lain.

Ketiga poin tersebut dinilai sebagai pondasi dasar yang diletakkan Presiden Soeharto untuk mempertahankan kekuasaannya. ABRI diberdayagunakan, bahkan fungsinya ditambah untuk merambah ke ranah sipil. Pemilu dan partai politik pun di desain agar semua dapat diatur oleh

${ }^{61}$ Nancy L Ruselblum and Robert C. Post, "Civil Society and Government", (United Kingdom: Princeton University Press, 2002), hal. 15.

${ }^{62}$ Republik Indonesia, Undang-Undang Dasar 1945, Pasal 28 dan Pasal 28 E.

63 Ahmad Yani, "Pembentukan Peraturan Perundang-Undangan yang Responsif: Catatan atas UU No 12 Tahun 2011 tentang Pembentukan Peraturan Perundang-Undangan”, (Jakarta: Konstitusi Press, 2013). hal. 8.

${ }^{64}$ Edward Aspinall, "Opposing Suharto: Compromise, Resistance, and Regime Change in Indonesia”, (California: Stanford University Press, 2005), hal. 22-23. 
pemerintah. Yang terakhir, adanya poros ABRI-Birokrasi-Golkar yang menjadi alat utama pada masa Orde Baru.

Pada awalnya kekuasaan Presiden Soeharto sejak tahun 1966 sampai dengan 1971, relatif konstitusional dan demokratis. Setelah itu, mulailah terjadi pergeseran secara pelan-pelan menuju pemerintahan yang menyimpang dari demokrasi yang sebelumnya telah diwujudkan dengan baik. ${ }^{65}$ Oleh karena itu, sejak tahun 1971 dan seterusnya, mulai banyak produk hukum, terutama dalam bidang politik, yang menggambarkan bagaimana pilihan politik yang otoriter dapat tercermin pada produk hukum yang dikeluarkan.

\section{Produk Hukum Pada Periode 1932-1998}

\section{Peraturan mengenai Pemilihan Umum}

Di dalam Pasal 1 Ayat (2) UUD 1945 disebutkan bahwa "kedaulatan berada di tangan rakyat". Muatan pasal ini menggambarkan bahwa Indonesia dalam menjalankan pemerintahannya berdasarkan nilai-nilai demokrasi. Pemerintahan yang demokrasi pada dasarnya merupakan bentuk pemerintahan yang menempatkan supremasi rakyat yang sangat kuat, karena istilah demokrasi menurut asal kata berarti "rakyat berkuasa" atau "government of rule by the people". ${ }^{66}$ Maka, sebagai bentuk terlaksananya demokrasi pada suatu negara, diadakanlah pemilihan umum.

Adanya pemilihan umum di dalam suatu negara menunjukkan bahwa negara tersebut merupakan negara demokrasi. Namun demikian, tidak semua negara demokrasi di dalam praktik kenegaraannya bersikap demokratis. Contohnya adalah Aljazair, yang pada tahun 80-an menyelenggarakan pemilu dengan FIS keluar sebagai pemenang pemilu. Akan tetapi, kemenangan tersebut membuat militer membatalkan pemilu. Hal tersebut menunjukkan bahwa negara yang melaksanakan pemilu tidak selalu demokratis, walaupun adanya pemilu tersebut untuk menunjukkan negara tersebut merupakan negara yang demokratis.

Di berbagai negara demokrasi, pemilihan umum merupakan ciri penting yang harus dilaksanakan secara berkala dalam waktu-waktu yang tertentu. ${ }^{67}$ Bahkan, pemilihan umum yang diselenggarakan secara berkala merupakan hal penting. Hal tersebut antara lain: ${ }^{68}$

\footnotetext{
${ }^{65}$ Ramly Hutabarat, "Politik Hukum Pemerintahan Soeharto tentang Demokrasi Politik di Indonesia (1971-1997)”, (Disertasi Doktor Universitas Indonesia, Jakarta, 2004), hal. 109.

${ }^{66}$ Miriam Budiardjo, "Dasar-Dasar Ilmu Politik", cet. Ke-3, (Jakarta: PT. Gramedia Pustaka Utama, 1978), hal. 50.

67 Jimly Asshiddiqie, "Pengantar Hukum Tata Negara Jilid II", (Jakarta: Konpress, 2006), hal. 169-170.
} 
1) Pendapat atau aspirasi rakyat mengenai berbagai aspek kehidupan berasama dalam masyarakat yang bersifat dinamis, dan berkembang dari waktu ke waktu.

2) Kondisi kehidupan bersama dalam masyarakat dapat pula berubah, baik karena dinamika dunia internasional ataupun karena faktor dalam negeri sendiri, baik karena faktor internal manusia ataupun eksternal manusia.

3) Perubahan-perubahan aspirasi dan pendapat rakyat juga dapat dimungkinkan terjadi karena pertambahan jumlah penduduk dan rakyat yang dewasa.

4) Untuk menjamin terjadinya pergantian kepemimpinan negara, baik di cabang kekuasaan eksekutif maupun legislatif.

Di dalam konteks mengadakan pemilihan umum secara berkala, maka setidaknya Indonesia sudah sebelas kali mengadakan pemilu legislatif, dan tiga kali untuk pemilu Presiden dalam rentang waktu tahun 1955-2014. Waktu pemilu yang dilaksanakan di Indonesia adalah tiap lima tahun sekali. ${ }^{69}$ Namun demikian, ada kondisi tertentu pemilu di Indonesia tidak terjadi secara lima tahun sekali. Misalnya, pemilu tahun 1999 merupakan pemilu yang dipercepat yang diselenggarakan pada masa pemerintahan B.J. Habbibie yang menggantikan Presiden Soeharto, yang mengundurkan diri karena desakan rakyat Indonesia melalui aksi demonstrasi. $^{70}$

Di dalam sebelas kali pemilu yang diadakan di Indonesia, landasan hukum yang digunakan pun berbeda. Pada pemilu tahun 1955, menggunakan Undang-Undang Nomor 7 Tahun 1953 tentang Pemilihan Umum. Lalu berturut-turut dalam pemilu tahun 1971 menggunakan Undang-Undang Nomor 15 Tahun 1969 tentang Pemilihan Umum Anggota-Anggota Badan Permusyawaratan/Perwakilan Rakyat, pemilu tahun 1977 menggunakan Undang-Undang Nomor 4 Tahun 1975 tentang Perubahan UU Nomor 15 Tahun 1969 tentang Pemilihan Umum Anggota-Anggota Badan Permusyawaratan/Perwakilan Rakyat, pemilu tahun 1982 menggunakan Undang-Undang Nomor 2 Tahun 1980 tentang Perubahan atas UU Nomor 15 Tahun 1969 tentang Pemilihan AnggotaAnggota Badan Permusyawaratan/Perwakilan Rakyat sebagaimana telah diubah dengan UU Nomor 4 Tahun 1975, pemilu tahun 1987, 1992, dan 1997 menggunakan dasar hukum yang sama, yakni Undang-Undang Nomor 1 Tahun 1985 tentang Perubahan atas UU Nomor 15 Tahun 1969 tentang Pemilihan Umum Anggota-Anggota Badan

${ }^{68}$ Ibid.

69 Indonesia (1), Undang-Undang Dasar Negara Republik Indonesia Tahun 1945 Perubahan Ketiga, Pasal 22E Ayat (1). Bunyi pasal tersebut adalah "Pemilihan umum dilaksanakan secara langsung, umum, bebas, rahasia, jujur, dan adil setiap lima tahun sekali”.

${ }^{70}$ Abdul Bari Azed dan Makmur Amir, Op.Cit., hal. 66. 
Permusyawaratan/Perwakilan Rakyat sebagaimana telah diubah dengan UU Nomor 4 Tahun 1975 dan UU Nomor 2 Tahun 1980. ${ }^{71}$ Setelah tiga kali pemilu menggunakan dasar hukum yang sama, pada akhirnya pemilu 1999 menggunakan dasar hukum yang berbeda, yakni Undang-Undang Nomor 3 Tahun 1999 tentang Pemilihan Umum.

Tahun 2004 merupakan tahun yang bersejarah bagi Indonesia. Pada tahun ini, untuk pertama kali Presiden dan Wakil Presiden dipilih secara langsung oleh rakyat. ${ }^{72}$ Pemilu tahun 2004 menggunakan dua landasan hukum, yakni Undang-Undang Nomor 12 tahun 2003 tentang Pemilihan Umum Anggota DPR, DPD, dan DPRD serta Undang-Undang Nomor 23 Tahun 2003 tentang Pemilihan Umum Presiden dan Wakil Presiden. Lalu, pada pemilu tahun 2009 menggunakan landasan hukum UndangUndang Nomor 10 Tahun 2008 tentang Pemilihan Umum Anggota DPR, DPD, dan DPRD serta Undang-Undang Nomor 42 Tahun 2008 tentang Pemilihan Umum Presiden dan Wakil Presiden. Terakhir, pada pemilu tahun 2014 menggunakan landasan hukum Undang-Undang Nomor 8 Tahun 2012 tentang Pemilihan Umum Anggota DPR, DPD, dan DPRD serta Undang-Undang Nomor 42 Tahun 2008 tentang Pemilihan Umum Presiden dan Wakil Presiden.

Pada masa Orde Baru, maka pemilu diselenggarakan dalam rentang waktu 1971-1997. Pemilu 1971 merupakan pemilu kedua setelah pemilu 1955. Penyelenggaraan pemilu pada 1971 merupakan amanat dari TAP MPRS Nomor XLII/MPRS/1968 tentang Perubahan Ketatapan MPRS/1966 tentang Pemilu yang menentukan bahwa penyelenggaraan pemilu yang tadinya selambat-lambatnya pada 5 Juli 1968 menjadi 5 Juli 1971. ${ }^{73}$ Untuk melaksanakan pemilu tersebut, maka dibentuklah UU Nomor 15 Tahun 1969 yang mengatur tentang Pemilu. Sebagai landasan pemilu 1971, maka dibentuklah UU Nomor 16 Tahun 1969 tentang Susunan dan Kedudukan MPR, DPR, dan DPRD. Di dalam Pasal 1 ayat (4) undang-undang tersebut disebutkan bahwa, "sepertiga dari seluruh anggota Majelis Permusyawaratan Rakyat ditetapkan melalui pengangkatan.", yang berarti 306 dari 920 anggota dilakukan melalui pengangkatan. Demikian pula pada Pasal 10 ayat (3) dalam undangundang ini yang menyebutkan bahwa dari 460 orang anggota DPR, yang dipilih sebanyak 360 orang dan 100 orang diangkat. Maka, pengangkatan anggota DPR seperti ini merupakan strategi Soeharto untuk menanamkan orang-orangnya pada parlemen.

${ }^{71}$ Ibid., hal. 58-66.

${ }^{72}$ Indonesia, Op.Cit.,Ps. 6A ayat (1). Pasal ini berbunyi, "Presiden dan Wakil Presiden dipilih dalam satu pasangan secara langsung oleh rakyat." Bandingkan ketentuan pasal ini dengan Pasal 6 Ayat (2) UUD 1945 sebelum perubahan yang berbunyi, "Presiden dan Wakil Presiden dipilih oleh Majelis Permusyawaratan Rakyat dengan suara yang terbanyak.”

${ }^{73}$ Ismail Suny, "Mencari Keadilan”, (Jakarta: Ghalia Indonesia, 1982), hal. 228. 
Pengangkatan diawal Orde Baru ini merupakan bagian tak terpisahkan dari politik hukum pemerintah untuk menciptakan kekuasaan legislatif yang kuat dan dapat dijadikan adanya payung legislatif yang berguna menjadi mitra pemerintah mewujudkan konfigurasi kekuasaan yang solid dan kooperatif. ${ }^{74}$ Adanya kemitraan antara parlemen dan pemerintah, maka produk hukum yang dikehendaki akan mudah diciptakan. Pembuataan UU oleh DPR dikerjakan oleh anggota yang mayoritas berasal dari Golkar sebagai partai pemerintah.

Pada 3 Juli 1971, pemilu pertama di era Orde Baru diadakan. Di dalam pemilu kali ini, Golkar sebagai "partai" pemerintah unggul dan berhasil memperoleh tidak kurang dari $65,56 \%$ atau 236 dari 360 kursi yang diperebutkan. Jika dihitung dari jumlah kursi di DPR sejumlah 460 kursi, maka Golkar memperoleh 236 kursi ditambah dengan 25 kursi yang diangkat, sehingga total menjadi 261 kursi atau sebesar 56,74\%. Pun dengan pemilu-pemilu selanjutnya hingga pemilu 1997, Golkar senantiasa tampil dengan suara terbanyak pada pemilu.

Di dalam pemilu era Orde Baru, terutama semenjak pemilu pada tahun 1977, telah terjadi pembatasan peserta pemilu hanya menjadi dua partai politik dan satu golongan karya. Hal tersebut tidak lepas dari lahirnya UU Nomor 3 Tahun 1975 tentang Partai Politik dan Golongan Karya. Begitu pula dengan pemilu tahun 1982, mengikuti pemilu tahun 1977, masih terdapat pembatasan kekuatan politik. Padahal, pembatasan tersebut merupakan penghancuran atas sifat demokratis dari demokrasi itu sendiri. Pembatasan jumlah partai politik yang berhak mengikuti pemilu tersebut dinilai merupakan strategi Presiden Soeharto untuk dapat mengelola kepentingan politik, dan juga untuk mempertahankan kekuaaannya.

Di dalam pemerintahan yang totaliter, pemilu tetap diadakan. Dalam hal ini, pemilu dijadikan sebagai alat legitimasi bahwa proses demokrasi berjalan dengan baik di dalam negara tersebut. Oleh karena itu, partai politik tetap diperlukan. Maka, Presiden Soeharto tetap memelihara jumlah partai secara terbatas untuk dapat memenuhi persyaratan demokrasi tersebut.

\section{Peraturan mengenai Fusi Partai Politik}

Penyederhanaan partai politik pada masa Orde Baru dinilai sebagai bentuk kegelisahan Presiden Soeharto atas sistem multipartai yang sering menciptakan instabilitas. Hal tersebut dapat dilihat dari pengalaman Presiden Soekarno yang menerapkan sistem multipartai, yang ternyata seringkali kabinet pemerintahan itu berganti. Maka, pembatasan partai politik digunakan agar kejadian di masa Orde lama tidak terulang kembali.

\footnotetext{
${ }^{74}$ Ramly Hutabarat, Op. Cit., hal. 116.
} 
Di dalam masa Orde Baru, partai politik masih diberikan keleluasaan bergerak sampai Pemilut 1971. Sesudah diadakannya Pemilu 1971, dimana Golkar menjadi pemenang pemilu, dan disusul oleh NU, Parmusi, dan PNI, agaknya partai-partai harus menerima kenyataan bahwa peranan mereka dalam decision making process untuk sementara tetap akan terbatas. ${ }^{75}$ Sebenarnya, bukan hanya terbatas, namun memang selain Golkar, partai-partai tersebut hanya sebagai pelengkap saja. Apalagi setelah keinginan Soeharto untuk melakukan penyederhanaan partai politik 1973 terwujud, sehingga hanya ada tiga partai politik, yaitu Golongan Karya (Golkar), Partai Persatuan Pembangunan (PPP), dan Partai Demokrasi Indonesia (PDI). PPP merupakan fusi dari empat partai Islam, yaitu Nahdatul Ulama (NU), Partai Muslimin Indonesia (Parmusi), Partai Sarikat Islam Indonesia (PSII), dan Perti. Sedangkan PDI merupakan fusi dari partai nasional sekuler dan Kristen yang terdiri dari empat partai, yaitu Partai Nasional Indonesia, Partai Katolik, Partai Murba, dan Partai Ikatan Pendukung Kemerdekaan Indonesia.

Fusi partai politik ini kemudian dituangkan kedalam UU Nomor 3 Tahun 1975 pada tanggal 27 Agustus 1975. Politik hukum ini pada akhirnya menempatkan fusi partai politik itu secara yuridis. Dari konsiderans menimbang UU ini menyebutkan empat hal yang disebutkan di bawah ini:

1) Bahwa dalam rangka penyederhanaan dan pendayagunaan kehidupan politik, dewasa ini organisasi-organisasi kekuatan sosial politik telah ada mengelompokkan diri menjadi dua partai politik dan satu Golongan Karya, seperti yang dinyatakan dalam GarisGaris Besar Haluan Negara.

2) Bahwa dengan adanya tiga organisasi kekuatan sosial politik dan Golongan Karya benar-benar dapat menjamin terpeliharanya persatuan dan kesatuan bangsa, stabilitas nasional serta terlaksananya percepatan pembangunan.

3) Bahwa agar saupaya kenyataan-kenyataan yang positif itu dapat tumbuh semakin kuat dan mantap, perlu diatur tata kehidupan partai-partai politik dan Golongan Karya tersebut, yang sekaligus memberikan kepastian tentang kedudukan fungsi, hak dan kewajiban yang sama dan sederajat dari organisasi-organisasi kekuatan sosial politik yang bersangkutan yang memadai serta sesuai dengan prinsip-prinsip Demokrasi Pancasila serta pelaksanaan pembangunan bangsa.

4) Pasal 27 dan 29 UUD 1945.

Landasan tersebut cukup memiliki logika dan konstitusi pembenaran penyederhanaan partai politik. Tetapi, perlu diingat pula bahwa di dalam demokrasi, pembatasan partai politik seperti ini dinilai tidak sesuai dengan demokrasi itu sendiri. Implikasi dari penyederhanaan partai

${ }^{75}$ Miriam Budiardjo, Op. Cit., hal.172. 
politik ini terhadap rakyat adalah munculnya ketidakpuasan untuk menyalurkan pendapat karena pilihan mereka sangat terbatas, hanya tiga.

Politik hukum penyederhanaan partai politik ini juga dinilai sebagai bentuk memperkuat dan mempertahankan kekuasaan eksekutif. Apalagi dengan terbitnya UU Nomor 3 Tahun 1975 tersebut, maka dapat dikatakan produk hukum ini merupakan implikasi dari rezim pemerintahan yang otoriter.

\section{Peraturan mengenai Susunan dan Kedudukan Anggota MPR, DPR, dan DPRD}

Pengisian anggota MPR, DPR, dan DPRD dilakukam melalui suatu undang-undang. Pada pemilu 1971, dasar hukum yang digunakan adalah UU Nomor 15 Tahun 1969. Sedangkan mengenai komposisi anggota MPR, DPR dan DPRD berdasarkan kepada UU Nomor 16 Tahun 1969 tentang Susunan dan Kedudukan MPR, DPR, dan DPRD, yang kemudian disempurnakan dengan UU Nomor 2 Tahun 1985. Di dalam pasal 2 ayat (1) UU tersebut disebutkan bahwa:

Majelis Permusyawaratan Rakyat terdiri atas anggota-anggota Dewan Perwakilan Rakyat, ditambah dengan utusan-utusan dari daerah-daerah dan golongan-golongan, menurut aturan yang ditetapkan dengan Undang-undang.

Menurut Pasal 2 ayat (3) UU tersebut, keanggotaan MPR diresmikan dengan Keputusan Presiden. Hal tersebut menarik karena artinya peranan Presiden sangat kuat dan dominan untuk menentukan susunan dan kedudukan MPR dan DPR. Karena pemilihan anggota MPR dan DPR tersebut adalah suatu produk hukum. ${ }^{76}$ Anggota MPR yang teridiri dari anggota DPR, Utusan Daerah, dan Utusan Golongan, juga ada yang berasal dari pengangkatan, yang merupakan produk hukum Orde Baru.

\section{Pengaruh Konfigurasi terhadap Produk Hukum yang dihasilkan}

Bentuk dan sifat pemerintahan yang dihasilkan oleh tiap-tiap pemerintahan berbeda-beda. Salah satu masa pemerintahan yang unik untuk dibahas adalah masa pemerintahan Soeharto dimana terkenal dengan sifat yang otoriter. Dalam perwujudan sebuah negara yang sedang menuju sebuah reformasi, maka dibutuhkan sebuah agenda untuk membangun good governance sebagai sebuah legitimasi tegaknya prinsip good governance itu sendiri yaitu transparansi, pluralisme, partisipasi masyarakat dalam pengambilan keputusan, representasi, dan akuntabilitas. $^{77}$ Selain itu, juga dibutuhkan penegakkan the rule of law

\footnotetext{
${ }^{76}$ Haji Muhammad Ridwan Indra, "Dalam UUD 1945 Kekuasaan Eksekutif Lebih Menonjol, (Executive Heavy)", Jakaerta: CV. Haji Masagung. tt), hal. 15.
} 
yang dipercaya dapat meningkatkan pertumbuhan ekonomi, modernisasi politik, perlindungan HAM dan tindakan anti korupsi.

Moh. Mahfud MD mengemukakan tentang hal tersebut bahwa terdapat tiga macam jawaban untuk melihat hubungan antara hukum dan politik. Pertama, hukum merupakan determinan politik, kegiatan politik harus tunduk pada hukum, Kedua, pandangan yang melihat bahwa politik determinan atas hukum karena sesungguhnya hukum adalah produk politik yang sarat dengan kepentingan dan konfigurasi politik, dan ketiga pandangan yang melihat bahwa hukum dan politik merupakan dua elemen subsistem kemasyarakatan yang seimbang, karena walaupun hukum merupakan produk politik maka ketika ada hukum yang mengatur aktivitas politik maka politikpun harus tunduk pada hukum. ${ }^{78}$ Ketiga bentuk ini memperlihatkan sebuah fenomena sistem politik yang dianut oleh tiap-tiap pemerintahan yang tidak akan sama di setiap pemerintahan di negara manapun.

Indonesia sendiri mempunyai bentuk konfigurasi politik yang berbeda di tiap pemerintahan. Hasilnya produk hukum yang dikeluarkan pun juga bergantung dari bentuk konfigurasi tersebut. Berikut tabel mengenai masa pemerintahan, konfigurasi politik dan bentuk produk hukum yang dihasilkan: ${ }^{79}$

\begin{tabular}{|l|l|l|lr|}
\hline No & $\begin{array}{l}\text { Periode } \\
\text { Pemerintahan }\end{array}$ & Konfigurasi Politik & $\begin{array}{l}\text { Bentuk Produk } \\
\text { Hukum }\end{array}$ \\
\hline 1 & $1945-1959$ & demokrasi liberal & responsif & \\
\hline 2 & $1959-1965$ & Otoriter & ortodoks \\
\hline 3 & $1966-1998$ & Otoriter & $\begin{array}{l}\text { ortodoks } \\
\text { konservatif }\end{array}$ \\
\hline 4 & $1998-$ sekarang & Demokratis & responsif & \\
\hline
\end{tabular}

Indonesia hanya mengalami dua kali masa dimana produk hukum yang dihasilkan bersifat responsif, yaitu masa awal kemerdekaan dan masa setelah reformasi. Produk hukum responsif sebagaimana disebutkan oleh Philip Nonet dan Philip Selznick bahwa cirinya adalah sensitif terhadap permasalahan namun tetap bertanggungjawab atas apa yang diatur oleh produk hukum tersebut.

Pada periode Soeharto, dengan dalih pembangunan nasional dan paradigma pertumbuhan ekonomi, konfigurasi politik didesain untuk membangun negara yang kuat yang mampu menjamin dan membentuk negara kuat, kehidupan politik yang stabil sengaja diciptakan karena pembangunan ekonomi hanya akan berhasil jika didukung oleh stabilitas nasional yang mantap. Pembangunan politik Orde Baru secara perlahan

77 Komisi Hukum Nasional, “Kebijakan Penegakan Hukum: Sebuah Rekomendasi”, (Jakarta: KHN, 2010), hal. 121.

\footnotetext{
${ }^{78}$ Mahfudz, "Politik Hukum di Indonesia", (Jakarta: PT. Grafindo, tt), tanpa halaman.

${ }^{79}$ Hasil pendataan oleh penulis dari masa ke masa pemerintahan dari berbagai sumber.
} 
membentuk konfigurasi politik yang otoriter dan totaliter. Eksekutif menjadi sangat dominan, kehidupan pers dikendalikan dan dibawah ancaman pembreidelan. Lembaga legislatif dicirikan sebagai lembaga yang lemah karena di dalamnya telah ditanamkan tangan-tangan ekskutif melalui Golongan Karya, Fraksi ABRI, Utusan Daerah dan Utusan Golongan. Partai politik dikebiri dengan menggunakan berbagai cara. Dikembangkan paradig-ma bahwa jumlah partai politik yang banyak berarti instabilitas bagi politik nasional. Oleh karena itu harus ada penyederhanaan sistem kepartaian, dengan memaksakan jumlah partai politik dua buah, yaitu Partai Persatuan Pembangunan dan Partai Demokrasi Indonesia, dan satu Golongan Karya. Lebih dari itu rekrutmen elit partai dilakukan dibawah kontrol sedemikian rupa oleh presiden, agar setiap potensi oposisi dan tokoh yang kritis tidak bisa tampil.

Pelaksanaan pemilu tidak lebih digunakan sekedar sebagai alat untuk memperoleh legitimasi formal. Sekalipun berhasil melaksanakan pemilu secara periodik, tetapi pemilu bukan dimaknai sebagai media untuk mewujudkan kehidupan politik yang demokratis, melainkan hanya sebagai suatu manuver politik untuk melanggengkan kekuasaan.

Pada masa rezim Orde Baru berkuasa, pemerintah membentuk berbagai lembaga represif seperti Kopkamtib, Opsus, Bakin dan lain-lain yang merupakan bagian dari strategi politik kekuasaan untuk mengamankan semua kebijakan dan kekuasaan Soeharto. Langkah ini dilakukan untuk pemantauan terhadap semua dimensi kehidupan sosial politik yang dianggap sebagai ancaman bagi kekuasaan dengan dalih demi stabilitas nasional dan kehidupan bangsa. Dengan siasat demikian pemerintah akan dengan mudah mengkontrol dan mengambil tindakan terhadap potensi perlawanan yang dianggap kritis dan membahayakan atau tidak sejalan dengan kebijakan pemerintah.

Pada masa pemerintahan rejim Orde baru melakukan berbagai bentuk tindakan yang mengarah pada depolitisasi masyarakat. Masyarakat dikondisikan sedemikian rupa agar apatis dan terisah dari politik. "Politik itu kotor", sehingga harus dijauhi. Beberapa hal dilakukan untuk mendepolitisasi masyarakat, diantaranya adalah:

1) Kebijakan massa mengambang (floating mass). Kebijakan ini adalah usaha rezim Orde Baru untuk menekan partisipasi politik masyarakat dalam pembangunan politik di tingkat lokal dengan melarang pembentukan kepengurusan partai politik sampai pada tingkat bawah. Kebijakan ini bertujuan untuk menciptakan kondisi agar masyarakat tidak menjadi a-politis dan tidak usah terlalu perduli dengan politik.

2) Pemilu untuk memperoleh legitimasi formal rezim Orde Baru sangat menyadari bahwa untuk membangun citra demokratis, harus dilaksanakan pemilu secara periodik dan diikuti oleh sebanyak mungin warga negara yang berhak memilih. Untuk itu dalam setiap pelaksanaan pemilu pemerintah perlu memobilisasi rakyat, agar tingkat partisipasi rakyat tinggi. Pemilu lebih dimaknai sebagai 
manuver politik rejim Orde Baru untuk melanggengkan kekuasaan negara.

3) Pengebirian/pengkerdilan peran partai politik. Pengkerdilan peran partai politik dibangun dengan hegemoni anti partai politik, karena dengan independensi partai politik berarti instabilitas dan disharmoni politik. Oleh karena itu perlu diadakan penyederhanaan sistem kepartaian dengan menggunakan palu godam, yaitu hanya Partai Persatuan Pembangunan untuk mengidentifikasi partai ideologi Islam, dan Partai Demokrasi Indonesia untuk mengidentifikasi ideologi nasionalis, dan Golongan Karya (tidak mau disebut partai politik). Ketiganya harus tunduk dengan pola penyeragaman, yaitu asas tunggal. Demikian juga rekruitmen fungsionaris partai harus diintervensi oleh pemerintah melalui jalur pembinaan politik oleh pemerintah.

4) Kontrol dan sentralisasi kehidupan politik. Logika yang dibangun untuk mengefektifkan kontrol dan pengawasan terhadap kehidupan politik yang sangat ketat demi pembangunan ekonomi nasional. Oleh karena itu dibentuk lembaga Kopkamtib, Opsusu, Bakin dan lainlain.

5) Dominasi militer dalam birokrasi (Dwi Fungsi ABRI). Sejarah pajang Orde Baru ditandai dengan pola distribusi posisi dan kebijakan strategis yang didominasim oleh anggota ABRI khususnya Angkatan Darat. Birokrasi menjadi instrumen pelaksana kekuasaan sekaligus mesin politik yang sangat efektif melindungi dan melanggengkan kekuasaan Soeharto.

Karakter produk hukum pemerintahan daerah pada masa Orde Baru ditandai dengan realitas UU No. 18 tahun 1965 yang ditetapkan pada tanggal 1 September 1965 tidak dapat berjalan dengan efektif karena adanya peristiwa $\mathrm{G} 30 \mathrm{~S}$ PKI yang segera diikuti dengan pergeseran kekuasaan politik ke Orde Baru. Pada awalnya pengaturan tentang pemerintahan daerah didasarkan pada Tap MPRS No. XXI/MPRS/1969 yang isinya menyatakan kepada Pemerintah Daerah dan DPRGR agar dalam waktu dekat memberikan otonomi yang seluas-luasnya kepada daerah-Daerah sesuai dengan jiwa dan isi UUD 1945 tanpa mengurangi tanggungjawab Pemerintah Pusat di Bidang perencanaan, koordinasi dan pengawasan terhadap Daerah-Daerah tersebut (Pasal 1).

Pelaksanaan amanat MPRS oleh pemerintah dan DPRGR ditetapkan dengan UU No. 6 tahun 1969 yang isinya menyatakan bahwa tidak berlakunya berbagai UU dan Perpu. Alasannya karena kondisi politik pada saat itu tidak memungkinkan menghasilkan UU penggantinya. Sehingga dalam prakteknya secara de facto UU No. 18 tahun 1965 tetap berlaku. Berikutnya pemerintah mengeluarkan UU No. 5 tahun 1974 tentang Pokok-Pokok Pemerintahan di Daerah sebagai pengganti UU No. 18 tahun 1965. Seiring dengan konfigurasi politik Orde baru yang semakin otoriter, produk hukum pemerintahan daerah inipun cende-rung 
berkarakter semakin konservatif/ortodoks. Dalam UU ini istilah otonomi yang nyata dan seluas-luasnya tidak lagi dipergunakan dan diganti degan otonomi yang nyata dan bertanggungjawab. Dominasi Pemerintah Pusat terhadap Daerah sangat menonjol. Hal ini dapat dilihat pada cara pengangkatan Kepala Daerah yang memberikan kekuasaan kepada Pemerintah Pusat untuk menentukannya tanpa terikat pada hasil pemilihan yang dilakukan oleh DPRD. Selain berperan sebagai organ daerah otonom, Kepala Daerah berkedudukan juga sebagai alat Pusat yang diletakkan di Daerah dengan sebut Kepala Wilayah. Dalam kedudukannya sebagai alat Pusat tersebut, Kepala Wilayah merupakan penguasa tunggal di daerah. Kontrol Pusat atas Daerah dilakukan melalui mekanisme pengewasan preventif, pengawasan represif, dan pengawasan umum.

\section{Penutup}

Indonesia mempunyai masa pemerintahan yang beraneka ragam baik dari segi bentuk pemerintahannya, konfigurasi politik serta produk hukum yang dihasilkannya. Dilihat dari masa ke masa konfigurasi politik di Indonesia berubah-ubah sesuai dengan bentuk pemerintahan dan karakter kepemimpinannya. Pada masa pemerintahan Soeharto dengan karakteristik kepemimpinanya yang terkesan otoriter membuat produk hukum yang dihasilkan bersifat ortodoks dan konservatif. Setiap kebijakan harus bersumber dari atas dan tidak sensitif dengan kebutuhan rakyat sehingga lebih membuat bungkam masyarakat, kreativitas dikebiri dan kritik dibatasi. Rakyat terlihat hanya sebagai objek dari pemerintahan itu sendiri. Padahal dalam sebuah negara, pemerintah dan rakyat adalah dua komponen yang saling mendukung bukannya meniadakan dan mengatasbawahi. Di negara-negara lain pun yang menganggap dirinya demokrasi selalu memberikan kebebasan yang bertanggungjawab kepada masyarakatnya sehingga masyarakat juga turut serta dalam pembangunan nasional. Maka, sudah tidak zamannya lagi untuk menjadikan rakyat sebagai sebuah fenomena keterbelakangan politik yang memunculkan otoriter dari pemerintah, kritik dan saran adalah sebuah keniscayaan yang harus dihadapi oleh setiap pucuk pimpinan yang seharusnya sudah disadari jauh sebelum mereka mencalonkan diri sebagai pemimpin negeri ini. 


\section{Daftar Pustaka}

Arinanto, Satya. Bahan Ajar Politik Hukum 2, Jakarta: Program Pascasarjana Fakultas Hukum Universitas Indonesia, 2004.

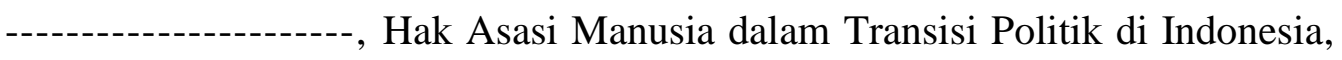
Jakarta: Pusat Studi Hukum Tata Negara, 2008.

Aspinall, Edward. Opposing Suharto: Compromise, Resistance, and Regime Change in Indonesia, California: Stanford University Press, 2005.

Budiardjo, Miriam. Dasar-Dasar Ilmu Politik, cet. Ke-3, Jakarta: PT. Gramedia Pustaka Utama, 1978.

Asshiddiqie, Jimly. Pengantar Hukum Tata Negara Jilid II, Jakarta: Konpress, 2006.

Bazed, Abdul Bari. Sistem-Sistem Pemilihan Umum: Suatu Himpunan Pemikiran, Ed. 1, Cet. 1, Jakarta: Badan Penerbit Fakultas Hukum Universitas Indonesia, 2000.

Catt, Helena. Democracy in Practice, London and Newyork: Routledge, 1999.

Fukuyama, Francis. Memperkuat Negara: Tata Pemerintahan dan Tata Dunia Abad 21, Jakarta: Gramedia, 2004.

Hutabarat, Ramly. Politik Hukum Pemerintahan Soeharto tentang Demokrasi Politik di Indonesia, Jakarta: Pusat Studi Hukum Tata Negara FHUI, 2005.

Indra, Haji Muhammad Ridwan. Dalam UUD 1945 Kekuasaan Eksekutif Lebih Menonjol, Jakarta: CV. Haji Masagung, tanpa tahun

Indrati, Maria Farida. Ilmu Perundang-Undangan, Yogyakarta: Kanisius, 2011.

Kelsen, Hans. General Theory of Law and State, London: Oxford University Press, 1949.

Komisi Hukum Nasional. Akar-Akar Mafia Peradilan di Indonesia: Masalah Akuntabilitas Penegak Hukum, Jakarta: Komisi Hukum Nasional, 2009.

Jakarta: KHN 2010.

Logeman, J.H.A. Theory of a Positive Constitutional Law, (Over De Theorie Van Een Stelling Staatsrecht), Perancis: Universitaire Pers Leiden, 1948.

Luciak, Iica. Pengawasan Parlementer atas Sektor Keamanan dan Gender, Jenewa: Geneva Center for The Democratic Control of Armed Forces (DCAF), 2008.

Mahfudz MD. Politik Hukum di Indonesia, Jakarta: PT. Grafindo, tanpa tahun.

Martiany, Dina. Siginifikansi Representasi Perempuan di Parlemen, Jakarta: P3DI Sekretariat Jenderal DPR Republik Indonesia, 2011. 
Moerdopo, Endang. Perempuan Keumala, Jakarta: Grasindo, 2008.

Nurtjahyo, Hendra. Filsafat Demokrasi, Jakarta: Bumi Aksara, 2006. Suplemen, Jakarta: PT Raja Grafindo Persada, 2005.

Parameter Kesetaraan Gender dalam Pembentukan Peraturan PerundangUndangan, Jakarta: Kementrian Pemberdayaan Perempuan dan Anak, 2012.

Pitkin, Hanna Fenichel. The Concept of Representation, London: University of California Press, 1967.

Ruselblum, Nancy L and Robert C. Post. Civil Society and Government, United Kingdom: Princeton University Press, 2002.

Subakti, Ramlan, dkk. Meningkatkan Keterwakilan Perempuan, Jakarta: Kemitraan Bagi Pembaruan Tata Pemerintahan, 2011.

Soekanto, Soerjono \& Purnadi Purbacaraka. Perihal Kaedah Hukum, Bandung: Citra Aditya Bakti, 1993.

Taghian, Syarif. Erdogan: Muadzin Istanbul Penakluk Sekularisme Turki, Jakarta: Al-Kautsar, 2012.

Yani, Ahmad. Pembentukan Peraturan Perundang-Undangan yang Responsif: Catatan atas UU No 12 Tahun 2011 tentang Pembentukan Peraturan Perundang-Undangan, Jakarta: Konstitusi Press, 2013.

\section{Disertasi/Makalah/Jurnal}

Krouse, Richard W. "Polyarchy \& Participation: The Changing Democratic Theory of Robert Dahl", dalam Polity, Vol. 14, No. 3, Spring, 1982.

Hutabarat, Ramly. "Politik Hukum Pemerintahan Soeharto tentang Demokrasi Politik di Indonesia (1971-1997)", Disertasi Doktor Universitas Indonesia, Jakarta, 2004.

Shanti, Budi. "Kuota Perempuan Parlemen: Jalan Menuju Kesetaraan Politik", Jurnal Perempuan No. 19, Jakarta: Yayasan Jurnal Perempuan. 2001.

\section{Internet}

Badan Pusat Statistik. Hasil Sensus Penduduk 2010, diunduh dari <http://dds.bps.go.id/ eng/aboutus.php?sp=0>, diakses tanggal 18 Juni 2012.

Stanford Encylopedia of Philosophhy. Political Representation, diunduh dari <http://plato.stanford.edu/entries/political-representation/>, diakses tanggal 10 Oktober 2012. 


\section{Undang-Undang}

Undang-Undang Dasar Negara Republik Indonesia Tahun 1945 Perubahan Ketiga.

Undang-Undang Dasar Negara Republik Indonesia Tahun 1945 Perubahan Keempat. 